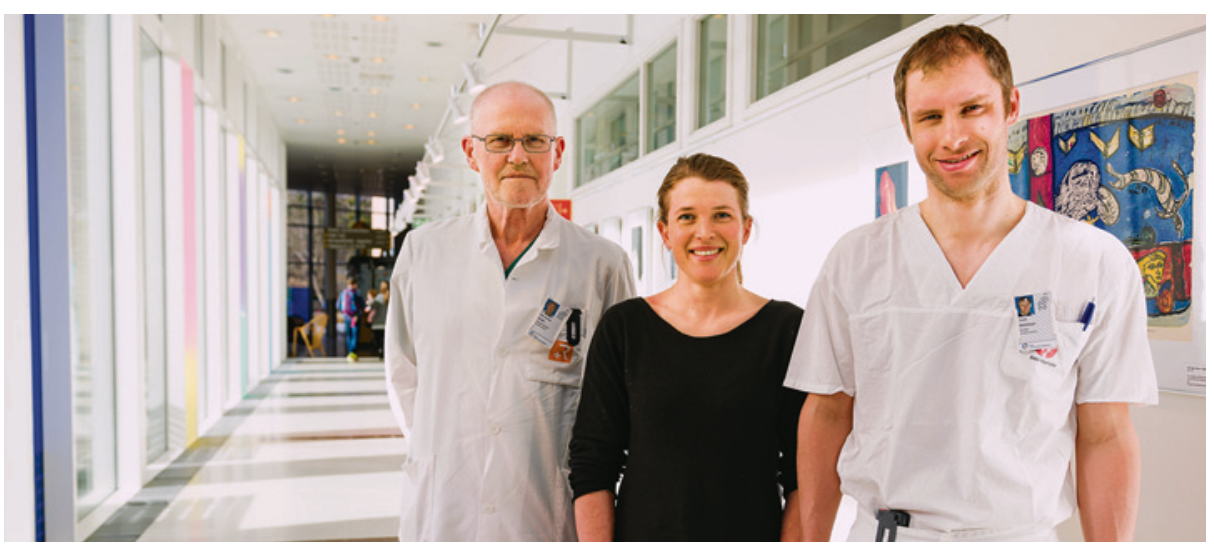

Fra venstre: Tom G. Tanbo, førsteforfatter Nora Johansen og Trond M. Michelsen. Foto: Øystein H. Horgmo, Universitetet i Oslo

MIN FøRSTE PUBLIKASJON

\title{
Redusert seksualfunksjon etter fjerning av eggstokkene
}

Kvinner med BRCA-mutasjon som har fått fjernet eggstokkene for å unngå eggstokkreft rapporterer mindre seksuell glede, mer seksuelle plager og sjeldnere sex. Dette viser en norsk studie.

Kvinner med BRCA-mutasjon har opp mot $60 \%$ risiko for å få eggstokkreft i løpet av livet. Det mest effektive tiltaket for å redusere denne risikoen er å fjerne eggstokker og eggledere på begge sider, noe som reduserer risikoen for eggstokkreft med rundt $80 \%$. En slik forebyggende operasjon er anbefalt utført rundt 40 års alder og fører da til umiddelbar menopause, som kan gi hetetokter, nattesvette, søvnforstyrrelser, tørre slimhinner i skjeden og redusert seksualfunksjon.

Studier har vist at mange kvinner opplever redusert seksualfunksjon etter operasjonen, mens studier om hvorvidt hormonbehandling hjelper eller ikke, er sprikende. I en norsk studie ble seksualfunksjon blant norske kvinner som hadde gjennomgått forebyggende fjerning av eggstokker undersøkt (1). Disse kvinnene og en kontrollgruppe fylte ut et spørreskjema om seksuell aktivitet og seksualfunksjon.

Kvinnene som hadde fått fjernet eggstokkene hadde mindre seksuell glede, mer seksuelle plager og sjeldnere sex enn kontrollkvinnene. Økt seksuell glede og mindre seksuelle plager var forbundet med lavere alder, det ikke å ha hatt kreft tidligere, bedre kroppsbilde og økt livskvalitet. Hormonbehandling hadde ingen innvirkning på seksuell glede, men de som brukte hormontilskudd hadde mindre seksuelle plager enn de som ikke brukte hormontilskudd.

- Resultatene støtter funnene fra tidligere studier, sier førsteforfatter Nora Johansen.

- Studien var en tverrsnittsstudie, og et slikt studiedesign er ikke egnet til å påvise årsaks- sammenheng mellom bruk av hormontilskudd og seksualfunksjon. Det kan være at kvinner med betydelig postmenopausale plager brukte hormontilskudd, og at kvinner med lite plager representerte ikke-brukerne. Effekten av hormonbehandling kan derfor ha blitt underestimert, sier Johansen.

- Det er viktig at kvinner som har fått påvist BRCA-mutasjon og skal ta valget om å bli operert, får grundig informasjon om uønskede effekter av å fjerne eggstokkene. For å hindre senplager bør kvinner som ikke har hatt brystkreft tidligere få hormontilskudd umiddelbart etter operasjonen og frem til 53 års alder, sier Johansen.

\section{Forskergruppen}

Denne studien er første artikkel i ph.d.-prosjektet til førsteforfatter Nora Johansen. Prosjektet omhandler sykelighet etter forebyggende fjerning av eggstokker og er et samarbeid mellom Sørlandet sykehus og Oslo universitetssykehus. Prosjektet ledes av Trond M. Michelsen ved Oslo universitetssykehus. Andre bidragsytere til studien var Astrid H. Liavaag ved Sørlandet sykehus Arendal og Tom Tanbo, Alv A. Dahl og Are H. Pripp ved Oslo universitetssykehus.

\section{Kaveh Rashidi}

Tidsskriftet

\section{Litteratur}

1. Johansen N, Liavaag AH, Tanbo TG et al. Sexua activity and functioning after risk-reducing salpingo-oophorectomy: Impact of hormone replacement therapy. Gynecol Oncol 2016; 140: 101-6.
Ordforklaringer

BRCA-mutasjon: Mutasjon i brystkreftgen 1 eller 2 (BRCA1, BRCA2) som gir økt risiko for utvikling av bryst-og eggstokkreft.

Tverrsnittstudie: En studiedesign der man samler informasjon på en planlagt måte i en definert populasjon på et gitt tidspunkt. 